\title{
Assessment of Farmers' Perciption on the Effects of Parthenium Hysterophorus on Grazing Land and Dairy Production in Damot Gale Woreda Wolaita Sodo, Ethiopia
}

\author{
Genet zelalem, Asfaw Tora* \\ Wolaitta Sodo University, College of Natural and Computational Science Department of Biology, Wolaita Sodo \\ University ETHIOPIA. \\ *Corresponding Author: Asfaw Tora, Wolaitta Sodo University, College of Natural and Computational \\ Science Department of Biology, Wolaita Sodo University ETHIOPIA.
}

\begin{abstract}
Parthenium hysterophorus (Parthenium weed) is an invasive alien species introduced deliberately or unintentionally from outside its natural habitat where it has the ability to establish itself, invade, out compete native species and take over the new environments. And enormous losses to cattle health and human health decrease quality and quantity of milk products and suffer allergic skin, asthmatic reactions in the Parthenium weed infested areas and in addition decrease crop and range land production have been observed. The study was concerned on assessing the perception of farmers that live in Damot gale woreda, Wolaita sodo, Ethiopia on the effect of parthenium hysterophorus on grazing land and dairy products. A cross sectional study was carried out to assess the perception of farmers and primary data was collected using semi structured interview questions and through direct observation on the field of study area.50 randomly selected respondents were participated of this (60\%) are male and the rest are female to answer the interview questions and the collected data were analyzed by using tables, percentages and finally expressed through full discussion. The study indicates that most people (44\%) call this weed "bazoo matta", some other people (36\%) knows its name as" worra matta "and (20\%) are said sharafa. The weed seed is easily spread by animals, wind, water, vehicles, farmer's seed, machinery and seed has distributed in all terrestrial lands like around road side, grazing land, farming land and others. The Parthenium weed cause "enormous losses to cattle health and human health, decrease quality and quantity of milk products and causes allergic skin. The control method taken by the society was uprooting, burning and using chemical. The farmers identified the problem of Parthenium weed effect on milk quality (changes color, taste) and they said it reduces the marketability of milk and milk quantity. Due to a serious problem of Parthenium weed on the grazing land and dairy products the researcher suggested that farmers should work hard on controlling the distribution of p.weed into non infested areas and it should be up rooted before flowering and when the soil is moist enough to facilitate easy removal.
\end{abstract}

Keywords: Dairy, Effect, Invasive, Parthenium hysterophorus

\section{BACKGROUND}

Parthenium hysterophorus (Parthenium weed) is an invasive alien species introduced deliberately or unintentionally from outside its natural habitat where it has the ability to establish itself, invade, out compete native species and take over the new environments. It is also known as white top, white head, congress grass or carrot grass belongs to family Asteraceae; is an erect annual herb with alternate deeply dissected leaves, growing up to $2 \mathrm{~m}$ tall originated either in the Gulf of Mexico or in Central South America (Navie et al., 1996). However, Parthenium weed has been observed to have as a parental plant under the agro-ecological condition of Pakistan (Hassan and Amin, 2009). Through accidental introduction it has been revealed considerable malleability and has spread to eastern and southern Africa, Southern USA, South Asia, the south China region, Vietnam, Australia and Pacific (Tamado and Milberg, 2000), and is known a serious weed of agriculture in India, Ethiopia, Australia and recently in other countries. Because of this status, it is recognized in the world top ten worst weeds (Mehdi, B.G, 1992). Parthenium hysterophrous Linn (Parthenium hysterophrous L.) an alien invasive weed is becoming a major weed of cropped and non-cropped areas in Africa (Adkins and Navie, 2006). In Africa, it was first recorded in 1980s and also recently introduced to many countries (Hussan et al., 2000). An earlier 1980s ecological survey of several location of Africa does not report $P$. weed from a 
single location (Anonymous, 2011). P.weed not only competes with desirable crops but also causes farmers and animals to suffer an allergic skin conditions while in contact with it (Chippendale and Panetta, 1994). Parts of Parthenium weed crops are allelopathic exhibiting strong competitive ability for soil moisture and nutrients while inhibiting the germination and growth of neighboring plant species (Adkins and Showery, 1996; Ashraf and Akhlqq, 2007). P. weed is the causal agent for serious economic, health, and environmental problems (Adkins et al., 1997).

Parthenium hysterophorus has infested almost all field crops farmers, waste lands, fencerows, and rights of way and when left uncontrolled, it can reduce crop yields (Navie et al., 1998). P. weed can badly impact agriculture, environment, human, and animal health and biodiversity and thus contribute to social and economic instability, placing constraints on suitable development economic growth, poverty alleviation and food security (Kohl et al., 2006).

Parthenium hysetrophorus has been quickly spreading in different parts of Ethiopia (Javari and Ritz, 2012). And enormous losses to cattle health and human health decrease quality and quantity of milk products and suffer allergic skin, asthmatic reactions in the Parthenium weed infested areas and in addition decrease crop and range land production have been observed. It is to be threatening to infest other fodder and cereal crops as well as vegetables like bitter, gourd and melons as well as timber crops (Shabbier and Bajwa, 2006). Therefore, this study aimed to assess the awareness of farmers on the effect of Parthenium hysterophorus on grazing land and dairy products in Damot Gale, Wolaita zone Southern Ethiopia.

\section{Methodology}

\subsection{Description of the Study Area}

Damot Gale is one of the woredas in the Southern Nations, Nationalities, and people' Region of Ethiopia. Part of the Wolaita zone, Damot Gale is bordered on south west by sodo zuria, on the northwest by Boloso sore and Damot pulasa, on the north by the Hadiya zone, on the east by Diguna Fango, and on the southeast by Damot Weyde. The administrative center of Damote Gale is Boditi and the kebeles found in the Damot Gale was Shashigale and Woshigale. Shashigale kebele has 650 households and Woshigale has 595 households, the majority of the in habitats were Protestants with $54.61 \%$ of the population reporting that beliefs $38.43 \%$ were Muslim and $1.28 \%$

was catholic. Domot Gale has $29 \mathrm{k} / \mathrm{m}$ of asphalt roads, 1 kilo meter of all-weather road and $57 \mathrm{k} / \mathrm{m}$ of dry weather roads, for an average road density of $209 \mathrm{k} / \mathrm{m}$ per 1000 square kilometers.

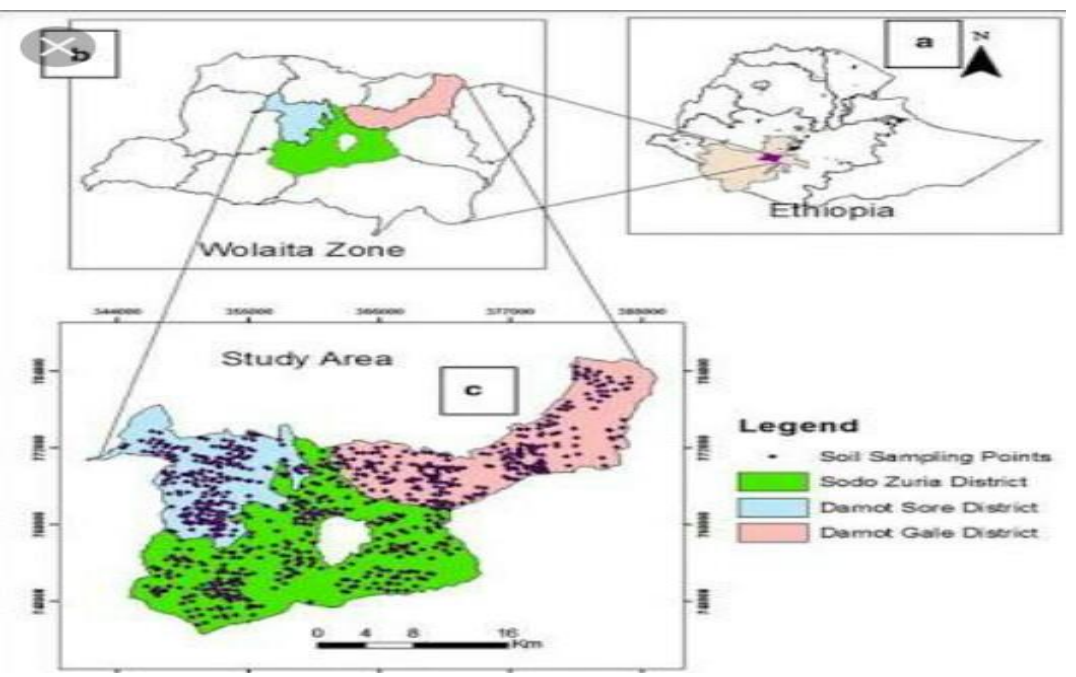

Fig1. Map of Damot Gale Woreda

\subsection{Study Design and Sample Size Determination}

A cross sectional study was carried out to assess the perception of farmers that live Wolaita Zone Damot Gale woreda on the effect of Parthenium hysterophorus on grazing land and dairy products. Due to lack of budget we select only 50 farmers by simple random technique from the inhabitants of the Shashigale and Woshigale kebeles. 
Assessment of Farmers' Perciption on the Effects of Parthenium Hysterophorus on Grazing Land and Dairy Production in Damot Gale Woreda Wolaita Sodo, Ethiopia

\subsection{Methods of Data Collection}

Primary data was collected using semi structured interview questions and through direct observation on the field in Wolaita zone, Damot Gale Woreda, Shashigale and Woshigale kebeles. Most questions were closed-ended in structure and collected by using interview. The data collected during the survey period included, knowledge information, attitude and practices of the community regarding the Parthenium weed dispersal and control method.

\subsection{Data Analysis}

The collected data was analyzed using tables, percentages and finally expressed through meaning full discussion.

\section{RESULTS AND DISCUSSION}

\subsection{Socio Demographic Characteristics}

Socio demographic characteristics such as in sex, educational status in different level like (primary, secondary, preparatory, and illiterates), religion (Orthodox, Muslim, Protestant) and marital status (single, widowed, married, divorced) of the study participants in Wolaita zone, Damot Gale woreda,Shashigale and Woshigale kebeles. The total number of farmers participated in this study: the male and female's number of respondent was $60 \%$ and $40 \%$ respectively, in the educational status of respondents are in primary $40 \%$, secondary $10 \%$, illiterates $50 \%$ but there is no respondent in the preparatory level, the religion status: orthodox $8 \%$, Muslim 38\%: protestants, $54 \%$ and the other socio demographic characteristics was marital status: married people was $50 \%$, single $20 \%$, widowed $10 \%$ and divorced $20 \%$ as shown in below table.

Table3.1. socio demographic characteristics of the study participants in Wolaita zone,Damot Gale woreda,in the Shashigale and Woshigale kebeles.

\begin{tabular}{|c|c|c|c|c|}
\hline No & \multicolumn{2}{|c|}{ Demographic and Socio economic variable } & No of respondent & Percentage of \\
\hline \multirow[t]{3}{*}{1} & \multirow[t]{3}{*}{ Sex } & Male & 30 & 40 \\
\hline & & Female & 20 & 100 \\
\hline & & Total & 50 & 100 \\
\hline \multirow[t]{5}{*}{2} & \multirow{5}{*}{$\begin{array}{c}\text { Educational } \\
\text { status }\end{array}$} & Primary & 20 & 40 \\
\hline & & Secondary & 5 & 10 \\
\hline & & Preparatory & - & - \\
\hline & & Illiterates & 25 & 50 \\
\hline & & Total & 50 & 100 \\
\hline \multirow[t]{4}{*}{3} & \multirow[t]{4}{*}{ Religion } & Orthodox & 4 & 8 \\
\hline & & Muslim & 19 & 38 \\
\hline & & Protestant & 27 & 54 \\
\hline & & Total & 50 & 100 \\
\hline \multirow[t]{5}{*}{4} & \multirow[t]{5}{*}{ Marital status } & Married & 25 & 50 \\
\hline & & Single & 10 & 20 \\
\hline & & Widowed & 5 & 10 \\
\hline & & Divorced & 10 & 20 \\
\hline & & Total & 50 & 100 \\
\hline
\end{tabular}

\subsection{Awareness of the Society on the Effects of Parthenium Weed on Grazing Land and Dairy} Products

The awareness of the society in Damot Gale woreda the male and female respondents was less on the parthenium weed effect on grazing land and products.The awareness of society's about parthenium weed effect in Damot Gale woreda,Shashigale and Woshigale kebeles the male respondents was 20\% and female $10 \%$ aware about the p.weed effect but the society not aware about its effect was in male $30 \%$ and in female $40 \%$; this indicated that the awareness of the society in Damot Gale woreda,in each kebeles was less specially females was not aware about the effect of parthenium weed on grazing land and dairy products as shown in table 2 . In addition to this, the society's called this weed in different local name like some respondents said "sharafa" some of them thought "Woora matta" and others said that "Bazoo matta" but most of respondent was not known its name because of their less awareness. Comparing with (Auld et al., 1983) the $p$. weed has different local name from place to place, as these researchers mentioned common name for this weed in Ethiopia which is related to our study. 
Assessment of Farmers' Perciption on the Effects of Parthenium Hysterophorus on Grazing Land and Dairy Production in Damot Gale Woreda Wolaita Sodo, Ethiopia

Table3.2. Awareness of on the effects of parthenium weed

\begin{tabular}{|c|c|c|c|c|}
\hline No & $\begin{array}{c}\text { Awareness of the society on } \\
\text { the p.weed }\end{array}$ & Sex & $\begin{array}{c}\text { Number of } \\
\text { respondents }\end{array}$ & $\begin{array}{c}\text { Number of } \\
\text { respondents }(\%)\end{array}$ \\
\hline 1 & \multirow{2}{*}{$\begin{array}{c}\text { Aware society's about the } \\
\text { effect of parthenium weed }\end{array}$} & Male & 10 & 20 \\
\cline { 3 - 5 } 2 & $\begin{array}{c}\text { The society's that was not } \\
\text { aware on the effect of p.weed }\end{array}$ & Female & 5 & 10 \\
\cline { 3 - 5 } & Total & Female & 15 & 30 \\
\hline & & $\mathbf{5 0}$ & 40 \\
\hline
\end{tabular}

\subsection{Distribution of Parthenium Weed}

The parthenium hysterophorus distribution site, it is distributed everywhere. This may be since run off intercrossing the roadside, grazing land, farming land and other areas. By this method the seed can be transferred from infestations area in to non-infestation area and easily dispersed.

As shown on table 3: $40 \%$ of the respondents mentioned that $P$. hysterophorus weed is highly distributed on farming land, followed by grazing land (36\%) and along the road side (24\%). The respondents also mentioned that it is distributed around dirty and moister places especially in places where animal waste doped and stored. The other reason is that Parthenium weed is able to produce large quantities of seeds from a single plant. (Hussan et al., 2000) said that Parthenium weed can produce large quantities of seed up to 100,000 per plant. Another study by (Tefera, 2002) also showed that $p$. weed spreads rapidly in all region of the country, along roads and railways in grazing areas and arable land strongly affecting crop production, animals and biodiversity.

Table3.3. Distribution areas of Parthenium weed.

\begin{tabular}{|c|c|c|c|}
\hline Number & Distribution area & number of respondents & $\begin{array}{c}\text { Percentage of } \\
\text { respondents ( \%) }\end{array}$ \\
\hline $\mathbf{1}$ & Road area. & 12 & 24 \\
\hline $\mathbf{2}$ & Grazing land & 18 & 36 \\
\hline $\mathbf{3}$ & Farming land & 20 & 40 \\
\hline & Total & 50 & 100 \\
\hline
\end{tabular}

\subsection{Seasonal Distribution and Dispersal Agents of Parthenium Hysterophorus}

The distribution season of $P$. hysterophorus, most of the respondents said that the distribution season of $P$. hysterophorus was in summer and some are in winter, although Parthenium hysterophorus is an annual weed, its infestation greatly differs from season to season, mostly dominate on summer. This is due the germination mostly occurred during wet season in autumn and summer, because the weed grows rapidly when it gets moisture, comfortable condition and nutrients.

Regarding on the distribution season of $P$. hysterophorus, $80 \%$ of the respondents said that the distribution season of $P$. hysterophorus was in summer, however $10 \%$ of respondents said Parthenium weed distributed in winter, $6 \%$ respondents said $p$. weed distributed in spring and $4 \%$ of the respondents said $p$. weed distributed in autumn.

As shown on (table: 4) P. hysterophorus can be dispersed by wind, animals and flood. $26 \%$ of the respondents said that $P$. hysterophorus dispersed by animals, $36 \%$ of the respondents said it is dispersed by wind and $38 \%$ said by flood and they also mentioned farming machinery or materials as additional dispersal agents. The seed of Parthenium weed spread around road sides and grazing land by means of vehicles, machinery, animals, and water since the seed is too small and light (Shabbier,A. and Bajwa.R, 2006).

Table3.4. Seasonal distribution and dispersal agents of Parthenium hysterophorus

\begin{tabular}{|c|l|l|l|}
\hline No. & Season & Number of respondents & Percent of respondents (\%) \\
\hline 1 & Season & & \\
\hline \multirow{3}{*}{} & Summer & 40 & 80 \\
\cline { 2 - 4 } & Winter & 5 & 10 \\
\cline { 2 - 4 } & Spring & 3 & 6 \\
\cline { 2 - 4 } & Autumn & 2 & 4 \\
\cline { 2 - 4 } & Total & 50 & 100 \\
\hline
\end{tabular}

International Journal of Medicinal Plants and Natural Products (IJMPNP) 
Assessment of Farmers' Perciption on the Effects of Parthenium Hysterophorus on Grazing Land and Dairy Production in Damot Gale Woreda Wolaita Sodo, Ethiopia

\begin{tabular}{|l|l|l|l|}
\hline 2 & Dispersal agents & & \\
\hline \multirow{2}{*}{} & Wind & 18 & 36 \\
\cline { 2 - 4 } & Animals & 13 & 26 \\
\cline { 2 - 4 } & Floods & 19 & 38 \\
\cline { 2 - 4 } & Total & 50 & 100 \\
\hline
\end{tabular}

\subsection{The Effect of Parthenium Weed on Grazing Land}

Parthenium weed reduce crop productivity and species biodiversity so it affects the grazing land and Some respondents mentioned that parthenium weed makes the soil infertile and hardened the land and this affects the productivity of grazing land and weaken the productivity the quality of grazing land. As shown on table 3.5: Among 50 respondents 22\% of them said Parthenium weed reduce species biodiversity, $32 \%$ of respondents said it affect the productivity of the grazing land and $46 \%$ of respondents said it reduce feed supply for animal. A related research also indicated that in Queensland (Australia), the species has invaded 170,000 kilo meter square of high quality of grazing areas causing losses to the cattle industry (Mcfdyen, 1992). In grazing lands, P. hysterophorus has the potential to exclude the most useful forage plants, thereby decreasing pasture productivity and, hence, the carrying capacity of the land (Navie et al. 1996). Furthermore, the roots of decaying P. hysterophorus plants can release certain soluble sesquiterpene lactones that inhibit the germination and growth of other plants (Navie et al. 1996; Evans 1997).

Table3.5. Effects of Parthenium hysterophorus on grazing land.

\begin{tabular}{|l|l|l|l|}
\hline No & Items & No. of respondents & Percentage of respondents (\%) \\
\hline 1 & reducing species biodiversity & 11 & 22 \\
\hline 2 & reducing feed supply for animal & 23 & 32 \\
\hline 3 & affects productivity of grazing land & 16 & 46 \\
\hline & Total & $\mathbf{5 0}$ & $\mathbf{1 0 0}$ \\
\hline
\end{tabular}

\subsection{The Effect of Parthenium Weed on Cattle Health and Dairy Products}

The effect of Parthenium weed has effect on the quality of milk explained that when cows feed on the weed the color of the milk is changed like getting bloody and its taste becomes bitter. On the other hand, they said the milk does not give much butter and it also causes of disease to cattle so, Parthenium hysterophorus has various impacts when feeding by cattle.

Regarding on the effect of Parthenium hysterophorus when feeding by cattle, $40 \%$ of the respondents did not know the effect of $p$. weed on cattle during feeding where as $20 \%$ of the respondents said it decrease the amount of milk, $24 \%$ of respondents said decrease the quality of milk and the rest $16 \%$ respondents said it causes disease to cattle.

According to Evans (1997) Majority of the livestock had problem with Parthenium weed due to its toxicity. Shabbier and Bajwa (2006) also reported enormous losses to cattle health and human health, decrease quality and quantity of milk products and suffer allergic skin, asthmatic reactions in the Parthenium weed infested areas and in addition decrease crop and range land production have been observed. (Evans,1997). (Tamado and Milberg, 2000) reported that Ethiopia is currently the worst affected country in the region. $P$. hysterophorus is currently considered to be the most important weed both in cropland and grazing areas by $90 \%$ of farmers in the lowlands of Ethiopia. (Narasimhan et al., 1977) stated that it strongly competes for soil moisture and nutrients. This shows that indirectly $p$. weed has negative impact on dairy products.

Table3.6. The effects of Parthenium weed on cattle health and milk quality and quantity during feed

\begin{tabular}{|l|l|l|l|}
\hline Number & $\begin{array}{l}\text { The effects of parthenium weed } \\
\text { during feed }\end{array}$ & $\begin{array}{l}\text { Number of } \\
\text { respondents }\end{array}$ & $\begin{array}{l}\text { Percentage of respondents } \\
(\%)\end{array}$ \\
\hline 1 & Decrease the amount of milk & 10 & 20 \\
\hline 2 & Causes disease to cow & 8 & 16 \\
\hline 3 & Decrease the quality of milk & 12 & 24 \\
\hline 4 & Did not know & 20 & 40 \\
\hline & Total & $\mathbf{5 0}$ & $\mathbf{1 0 0}$ \\
\hline
\end{tabular}


Assessment of Farmers' Perciption on the Effects of Parthenium Hysterophorus on Grazing Land and Dairy Production in Damot Gale Woreda Wolaita Sodo, Ethiopia

\subsection{Control Methods of Parthenium Weed}

The most common methods of Parthenium hysterophorus practiced was manual methods to the farming land and in grazing land by uprooting the weed out group of agricultural season.

Most of respondents said that there are many herbicides available in market for controlling the weed and we use at time of $p$ weed germination. Parsons and Cuthbertson (1992) also reported that farmer lands should be managed efficiently, because poorly managed farmers increase the chance of invasion by $P$. hysterophrous and the severity of existing infestations.

Among the 50 respondents, as shown in the table, 56\% participants mentioned that the measure taken to control Parthenium weed is by manual followed by burning $24 \%$ participants and the rest $20 \%$ by using chemicals and some respondents said that, it is necessary to control the problematic weed parthenium hysterophorus in time by uprooting before flowering. For better management of the weed knowing the habitat, morphology and biology of the weeds is very important.

Table3.7. Control methods of Parthenium hysterophorus

\begin{tabular}{|l|l|l|l|}
\hline Number & $\begin{array}{l}\text { Control methods of parthenium } \\
\text { weed from the grazing land. }\end{array}$ & $\begin{array}{l}\text { Number of } \\
\text { respondents }\end{array}$ & $\begin{array}{c}\text { Percents of respondents } \\
(\boldsymbol{\%})\end{array}$ \\
\hline 1 & Manual & 28 & 56 \\
\hline 2 & Burning & 12 & 24 \\
\hline 3 & Use of chemical & 10 & 20 \\
\hline & Total & $\mathbf{5 0}$ & $\mathbf{1 0 0}$ \\
\hline
\end{tabular}

\subsection{Methods of Controlling Parthenium Weed Dispersion to New Place}

Parthenium weed, like any other weeds, can be dispersed easily by water, farm machinery, vehicles, movement of livestock, animal dung and grain seeds. Proper cleaning of farm equipment, sowing of uncontaminated seed and a short-term quarantine of livestock in Parthenium weed infested area uprooting before flower and burning without transporting to far area will reduce the risk of spreading the weed.

Most respondents (50\%) were said that both ( burning without transporting to far place and uprooting before flowering) are the best way to control the spread of seed weed to new place, $26 \%$ of respondents were said uprooting before flowering and $24 \%$ of respondents said that burning without transporting far place and also Tamado (2001) reported that Parthenium weed, like any other weeds, can be dispersed easily by water, farm machinery, vehicles, movement of livestock, animal dung and grain seeds.

Table3.8. controlling dispersion of weed seed.

\begin{tabular}{|l|l|l|l|}
\hline No & $\begin{array}{l}\text { Method of controlling seed } \\
\text { dispersion of parthenium weed }\end{array}$ & Number of respondents & Percentage of respondents (\%) \\
\hline 1 & $\begin{array}{l}\text { Burning without transporting to } \\
\text { far place }\end{array}$ & 12 & 24 \\
\hline 2 & Uprooting before flowering & 13 & 26 \\
\hline 3 & Both & 25 & 50 \\
\hline & Total & 50 & 100 \\
\hline
\end{tabular}

\subsection{Field Observation}

As we observed in Damot Gale woreda,in shashigale and woshigale kebeles during data collection the distribution of Parthenium weeds around grazing land, faming land, and roadside and also in waste place it is highly dominate farm land followed by grazing land and also we have seen the cattle and other animals also eat this weed because of scarcity of grass in area.

\section{CONCLUSIONS AND RECOMMENDATION}

From this study it is found that almost all the respondents or farmers living in Damot gale woreda, knew Parthenium weed and its presence in their environment. The study also indicated that some of farmers identified the effect of Parthenium hysterophorus weed on milk quality and quantity, and its effect on human and animal health, on cattle, on grazing land and the environment. But many respondents do not know about the effect of Parthenium weed on the health of cattle and their products. Due to this reason those farmers who do not identify its effect use the weed to feed their cattle when there is no grass or fodder. 
The weed grows in grazing land, farming land, roadside, waste land and wet lands. The farmers control this weed by hand picking method to eliminate Parthenium weed in villages and gardens and they do not have suitable equipment to use. It can germinate and produce seeds throughout the year and can cause serious problems on human beings, animals, crop production and biodiversity. Since it is an invasive alien weed and the handling method used by farmers is not effective it is expected to continue its dissemination and its effect will be serious on the grazing land, on dairy product as well as on the environment.

Based on the results, training farmers how to control weeds in many options and give equipment's used for controlling Parthenium weed advice to not use manual method of tap rooting weed in hand that causes allergic and integrated long term management program must be carried out to control the weed. It will require coordination among the local people, scientists, governments, and NGOs to work in unity.

\section{ACKNOWLEDGEMENTS}

Authors are grateful to the local people of Damot Gale district of Wolaita Zone for their hospitality and kind responses to our inquiries on information about their indigenous knowledge on assessment of farmers' perception on the effects of parthenium hysterophorus on grazing land and dairy production; Wolaita Sodo University for financial, material and technical support.

\section{REFERENCES}

[1] Adkins.S.WandM.S.Sowerby(1996).Allelopathic potential of the weed parthenium hystrophrous L., In Australia, plant prot.Qurt., 11:20-23.

[2] Adkins. S.W., S.C, Navie, G.C, Graham and R.E, McFadyen, (1997). Parthenium weed in Australia; research under way at the co-operative research center for tropical pest manage. Pros, first int. cone, on Parthenium management, univer of Agric. Sci, Dharwad, India, 6-8 oct, 1:13-17.

[3] Anonymous (2011) chapter17. Ecology, http:/prr.hec,gov.pk/chapters /1432-17. Pdf, accessed on May 28, 2011.

[4] Asharf.M, and Akhlaq.M, (2007). Effect of sorghum leaves, roots and stems water extract, hand weeding and herbicide on weed suppression and yield of wheat. Pak. Sarhad j. agric., 23(2):319-327.

[5] Chippendale. J.F, and Panetta. F.D, (1994). The cost of Parthenium weeds status and the possibilities for biological control. Biological control news and information. 18:89-98.

[6] Hassan.G and Amin.A (2009). First annual tech. Report-HEC international linkage project with univerof Queens land, Australia, on Parthenium weed.

[7] Hussan,S.S (2000). Report on alien's invasive species of Pakistan. Collaborate study of IUCN Pakistan.

[8] Javaid.A. and Riaz.T, (2012). Parthenium hysterophorus, an aliens invasive weed threatening natural vegetation in punja, pakistain. Park.J, Bot., 44(SI):123-126.

[9] Kohli,R.K. (2006). Status, invasiveness weeds in India Biol. Invasion, 8:1510.

[10] Mehdi B.G. (1992). Partheniumhysterophorus, anew weed problem in Ethiopia.FAO plantprot.Bull.

[11] Navie, S.C., Mcfadgen, R.E., panetta, F.D and Adkins, S.W, (1996). The biology of Australia weeds 27. Parthenium hysterophorus, plant protection Quarterly 11:75-88.

[12] Navie, S.C., Panetta, F.D., Mcfadyen R. E, and Adkins,S.W(1998).Behavior of buried and surface own weed of Parthenium hysterophorus. Weed Res, 38:335-341.

[13] Shabbier, A. and Bajwa.R, (2006). Distributions of Parthenium weed: an aliens invasive weed species threatening the biodiversity of Islamabad weed Biol, and Mang., 6:89-95.

[14] TamadoTena,and Millberg.P, (2000).Weed flora in arable field of eastern Ethiopia with emphasis on the occurance of Parthenium hysterophorus. Weeds boil research 40:507-52.

Citation: Tora, A \& Genet zelalem. (2019). Assessment of Farmers' Perciption on the Effects of Parthenium Hysterophorus on Grazing Land and Dairy Production in Damot Gale Woreda Wolaita Sodo, Ethiopia. International Journal of Medicinal Plants and Natural Products (IJMPNP), 5(1), pp.1-7. http://dx.doi.org/10.20431/2454-7999.0501001

Copyright: () 2019 Authors, This is an open-access article distributed under the terms of the Creative Commons Attribution License, which permits unrestricted use, distribution, and reproduction in any medium, provided the original author and source are credited. 